\title{
Globalisation contested
}

\author{
An international \\ political economy of work
}

\author{
LOUISE AMOORE
}




\section{$\infty$ \\ Globalisation contested}

$\infty$

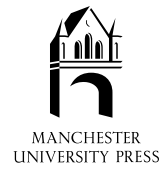


Louise Amoore - 9781526137418

Downloaded from manchesterhive.com at 04/26/2023 10:15:41AM via free access 


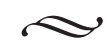

\title{
Globalisation contested
}

An international political economy of work

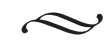

\section{LOUISE AMOORE}

\author{
Manchester University Press \\ Manchester and New York \\ Distributed exclusively in the USA by Palgrave
}


Copyright (c) Louise Amoore 2002

The right of Louise Amoore to be identified as the author of this work has been asserted by her in accordance with the Copyright, Designs and Patents Act 1988

Published by Manchester University Press

Oxford Road, Manchester M13 9NR, UK

and Room 400, 175 Fifth Avenue, New York, NY 10010, USA

http://www.manchesteruniversitypress.co.uk

Distributed exclusively in the USA by

Palgrave, 175 Fifth Avenue, New York, NY 10010, USA

Distributed exclusively in Canada by

UBC Press, University of British Columbia, 2029 West Mall,

Vancouver, BC, Canada V6T 1Z2

British Library Cataloguing-in-Publication Data

A catalogue record for this book is available from the British Library

Library of Congress Cataloging-in-Publication Data applied for

ISBN 0719060966 hardback

First published 2002

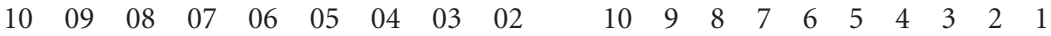

Typeset in Minion and Minion Display

by Koinonia, Manchester

Printed in Great Britain

by Biddles Ltd, Guildford and King's Lynn 